\title{
A Next Generation Electronic Bulletin Board Supporting N-Screen for a College Information System
}

\author{
Jae Heung Park ${ }^{\dagger} \cdot$ Yeong Geon Seo ${ }^{++}$
}

\begin{abstract}
The information delivery and transmission media(DID or PID) market is making remarkable growth as the high-speed networks are spreading and LCD/LED TVs are more and more popularized, and display devices are increasingly large and high-definition. In addition, the popularization of smart devices and the expansion of the information delivery and transmission media market make a demand for $\mathrm{N}$-Screen in content service. Colleges and universities have installed and operated various types of DID to promote their schools and departments and deliver information about them, still remaining in the level of media content implementation. So, we implement and evaluate a next-generation electronic bulletin board for each department that allows for interactive $\mathrm{N}$-Screen communication based on the integration of smart phone and internet. This board enhanced efficiency as supporting $\mathrm{N}$-Screen, inserting and deleting the contents at real time and offering bidirectional communication.
\end{abstract}

Keywords: BBS, N-Screen, University Information System, DID

\section{대학정보시스템을 위한 N-Screen 지원 차세대 전자게시판}

\author{
박 재 흥 ${ }^{+}$서 영 건 ${ }^{++}$
}

요 약

\begin{abstract}
고속 네트워크의 보급과 $\mathrm{LCD} / \mathrm{LED} \mathrm{TV}$ 보급의 증대, 디스플레이장치의 대형화와 고해상도화로 인하여 정보전달전송매체(DID 또는 $\mathrm{PID})$ 시 장이 크게 성장하고 있고, 스마트 기기의 대중화와 정보전달전송매체 시장의 확대는 콘텐츠 서비스의 N-Screen화를 요구한다. 대학에서도 학교 및 학과의 홍보 및 정보 전달을 목적으로 다양한 형태의 $\mathrm{DID}$ 를 설치, 운영 중에 있으나 아직은 미디어콘텐츠를 실행 시키는 수준에 머물러 있 다. 이에 대학에서 스마트 폰과 인터넷이 통합된 양방향 N-Screen 통신이 가능한 차세대 전자게시판을 구현하고 평가한다. 본 게시판은 $\mathrm{N}-\mathrm{Screen}$ 을 지원하고, 게시물을 실시간으로 삽입, 삭제할 수 있고, 양방향 통신을 제공하여 효율성을 높였다.
\end{abstract}

키워드 : 전자게시판, N-Screen, 대학정보시스템, DID

\section{1. 서 론}

고속 네트워크의 보급과 $\mathrm{LCD} / \mathrm{LED} \mathrm{TV}$ 보급의 증대, 디 스플레이장치의 대형화, 고해상도화에 따라 정보전달전송매 체(DID, Digital Information Display) 시장이 크게 성장하고 있다[1, 2]. 더욱이 스마트 기기의 대중화와 DID 시장의 확대는 콘텐츠 서비스의 N-Screen화를 요구한다[3, 4]. $\mathrm{DID}$ 는 과거 $\mathrm{LCD} / \mathrm{PDP} \mathrm{TV}$ 와 $\mathrm{VTR}$ 등의 매체 재생기를 통 하여 미리 저장되어 있는 광고나 홍보 영상 등을 디스플레 이 해주는 것으로, 기존의 TV와 VTR의 개념에서 크게 벗

† 정 회 원 : 경상대학교 컴퓨터과학과 교수

† 종신회원 : 경상대학교 컴퓨터과학과 교수

논문접수 : 2012년 9월 6일

수 정 일 : 1 차 2012년 11 월 12 일

심사완료: 2012년 11월 12일

* Corresponding Author: Yeong Geon Seo(young@gnu.ac.kr)
어나지 않은 방식이었다. 그러나 현재는 임베디드 시스템과 결합되어 외부 매체 재생기 없이도 저장장치나 네트워크를 통하여 각종 콘텐츠나 정보의 실시간 제공이 가능하다. 이 러한 $\mathrm{DID}$ 는 $\mathrm{TV}$ 의 개념이 아닌 하나의 홍보기기로 탈바꿈 하여 그 시장이 형성되게 되었고, 현재 시장에서 각광을 받 으며 그 비중이 점점 증가하고 있는 추세이다. 최근에는 기 관의 홍보나 광고, 정보전달을 위하여 설치된 $\mathrm{DID}$ 를 이용해 다양한 미디어를 즐기며 터치스크린으로 양방향 정보 전달 이 가능하다. 대학에서도 학교 및 학과의 홍보 및 정보 전 달을 목적으로 다양한 형태의 $\mathrm{DID}$ 를 설치, 운영 중에 있으 나 아직은 미디어콘텐츠를 실행 시키는 수준에 머물러 있 다. 이에 대학에서 스마트 폰과 인터넷이 통합된 양방향 $\mathrm{N}-\mathrm{Screen}$ 커뮤니케이션이 가능한 학과 전자게시판인 차세 대 전자게시판을 설계 및 개발하였다. 
대학의 업무는 대학 내 구성원(학생, 교수, 직원등)간의 의사소통과 정보전달을 통해 신속히 처리된다. 그 중 학생 과의 의사소통에 관심을 가진 것이 차세대 전자게시판이다. 학생은 입학과 동시에 학사 관련 각종 규정과 제도의 틀 속 에서 교과목을 이수하고, 성적을 취득하며, 졸업에 이르게 되는데 이러한 일련의 과정 속에서 관련 규정과 제도는 여 러 형태로 학생들에게 전달되어 져야 한다[5]. 대학은 이러 한 일련의 학사 업무를 학과지원과를 통해 처리한다. 그리 고 학과지원과는 학교와 학생의 소통의 장소로 학생들에게 정보를 알리거나 의사소통을 할 때 웹 홈페이지나 LED전광 판, 현수막, 교내에 비치된 게시판 등을 이용하고 있다. 이 중 가장 불필요한 인력 소모가 많은 것이 오프라인 게시판 이다. 오프라인 게시판은 게시물의 우선순위 선택에 따른 시간과 노력 소모, 게시판 인테리어의 취약 및 관리의 효율 성 저하, 표출 정보의 제한성에 따른 정보 전달의 효과 미 흡, 정보 전달의 시공간 제약점이라는 큰 문제를 안고 있다.

차세대 전자게시판은 기존의 오프라인 게시판을 전자게시 판으로 개발 한 것으로 차세대 전자게시판시스템을 이용하여 대학과 학과가 원하는 정보를 게시하고 학생은 $\mathrm{LCD}$ 스크린, 모바일 등을 이용하여 원하는 장소에서 정보를 확인할 수 있 는 시스템이다. 차세대 전자게시판 시스템은 콘텐츠 전파 기 능, $\mathrm{N}-\mathrm{Screen}$ 지원 기능, 관리자의 이메일 전송 기능, 게시물 등재에 따른 SMS알림 기능, 클라이언트 원격관리 기능을 지 원하며 기존 대학정보 시스템과도 연동이 가능하다.

\section{2. 관련 연구}

본 장에서는 $\mathrm{DID}$ 의 정의와 대학정보시스템, 기존 전자 게시판을 살펴보고 문제점을 기술한다.

\subsection{DID}

최근 홍보영상이나 간단한 정보를 전달하기 위해 건물의 옥내외에 $\mathrm{LCD} / \mathrm{PDP}$ 가 설치된 경우를 볼 수 있는데 이것을 디지털게시판이라고 하며[6], 정보전달전송매체는 DID 또는 PID(Public Information Display)로 불리는데 요즈음은 DID 라는 용어가 일반화 되었다. 기존 오프라인 광고매체가 정지 또는 롤링 방식, $\mathrm{LED}$ 전광판 형태로 제한된 글자나 이미지 를 보여주는 것과는 달리 $\mathrm{TV}$ 처럼 다채로운 영상을 보여줄 수 있다는 게 $\mathrm{DID}$ 의 강점이다[7]. 보통 $\mathrm{DID}$ 는 연중 365 일 가동할 수 있어야 하고, 야외에서도 고장이 없어야 한다는 점에서 일반 디스플레이보다 수명, 밝기, 시인성, 불순물로부 터 화면보호 등 기능이 우수해야 한다. 이러한 특성을 바탕 으로 야외에서 무난히 쓸 수 있는 순수 $\mathrm{DID}$, 주로 실내용으 로 쓰이는 하이브리드 $\mathrm{DID}$, 가정과 유사한 환경에서 쓰이는 상업용 TV 등 다양한 형태로 제작되고 있다 $[2,8]$.

$\mathrm{DID}$ 환경 구축 방식을 살펴보면 과거에는 $\mathrm{LCD} / \mathrm{PDP} \mathrm{TV}$ 와 VTR등의 매체 재생기를 통해 미리 저장되어 있는 광고 나 홍보 영상을 디스플레이 해주는 것이었으나 현재는 임베 디드 시스템과 결합되어 외부 매체 재생기 없이도 저장장치
나 네트워크를 통하여 콘텐츠나 정보를 실시간으로 제공한 다. 최근에는 고속 모바일 네트워크 보급과 스마트 기기의 대중화에 따라 제한된 디스플레이에서 정보를 제공받는 것 에서 나아가 다양한 표시 장치에서 서비스를 이용할 수 있 는 N-Screen과의 기술 접목도 필요로 하고 있다[3, 9].

$\mathrm{N}-\mathrm{Screen}$ 은 $\mathrm{TV}$ 나 $\mathrm{PC}$, 태블릿PC, 스마트폰 등 다양한 기기에서 하나의 콘텐츠를 끊김 없이 이용할 수 있게 해주 는 서비스를 말한다. 국내외 이동통신사들은 N-Screen을 통 해 사용자들이 자사 서비스를 이용하는 시간이 늘어날수록 영화, 드라마 등 콘텐츠를 구입할 가능성이 높아져 궁극적 으로 콘텐츠 매출을 늘릴 수 있기 때문에 미래 핵심서비스 로 인지해 시장 선점을 위해 경쟁하고 있다 $[6,10]$.

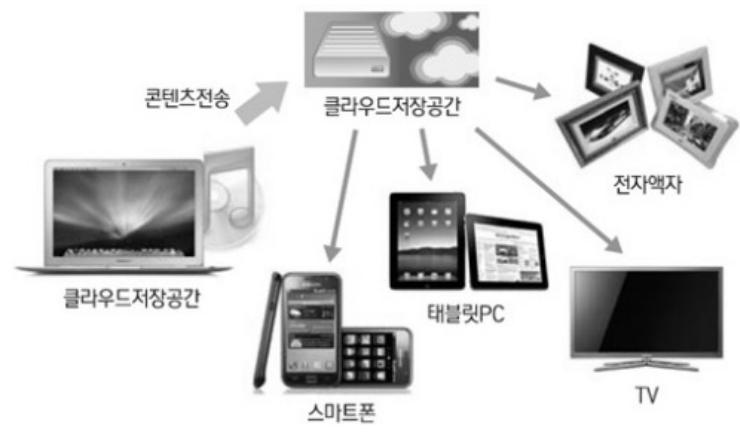

Fig. 1. Conception of $\mathrm{N}-\mathrm{Screen}$

$\mathrm{DID}$ 의 대표적인 응용분야는 상업용 광고분야, 제품/서비 스/이미지 등의 홍보 분야, 주요 이벤트/프로모션 공지나 길 안내 등의 정보 전달 분야가 있다. 이러한 $\mathrm{DID}$ 는 용도에 따 라 하나의 분야로 사용되어지기도 하지만 광고/정보전달, 홍 보/정보전달, 광고/홍보, 광고/홍보/정보전달 등과 같이 여러 분야를 혼합해 사용하기도 한다. 좁은 의미에서 $\mathrm{DID}$ 는 하드 웨어 측면을 강조한 용어로 저렴한 가격, 고품질, 대형화를 지향하고 있으며 최근에는 스마트 윈도우, $3 \mathrm{D}$ 분야와의 접목 을 통해 더욱 발전할 것으로 보인다. 그러나 넓은 의미에서 $\mathrm{DID}$ 는 소프트웨어, 하드웨어, 콘텐츠, 네트워크 등 다양한 정보기술이 복합적으로 이루어져 정보와 광고를 전달하는 디지털 영상장치이다.

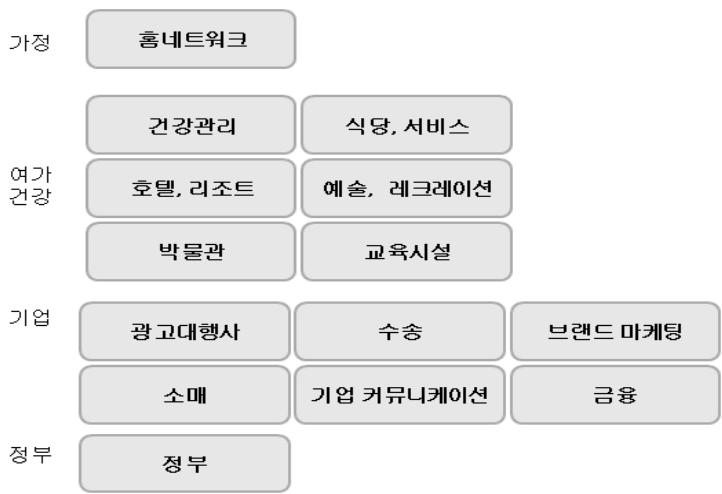

Fig. 2. Applications of DID 


\section{2 대학정보 시스템}

대학의 업무는 교원, 직원, 학생의 인적 구성원간의 의사 소통과 정보전달을 기반으로 이루어진다. 특히, 학생은 입학 과 함께 대학에서 학사 규정, 교과목을 이수, 학기별 시간표 , 성적 , 취업 등의 정보를 제공 받을 권리를 가진다. 이에 학사정보, 커뮤니티정보, 진학 정보등을 처리하고 학생에게 전달하고 피드백을 하는 일련의 과정을 대학정보시스템이라 고 한다[5]. 대학정보시스템은 업무에 따라 학사정보전달, 민 원처리, 학사업무일괄처리 시스템으로 분류한다.

Table 1. Affairs about instruction

\begin{tabular}{|c|c|}
\hline \begin{tabular}{l|} 
수업관련 \\
업무
\end{tabular} & 정의 \\
\hline $\begin{array}{l}\text { 수강 } \\
\text { 신청 }\end{array}$ & $\begin{array}{l}\text { 대학교(각 학과)에서 정한 교육과정 이수를 위하여 } \\
\text { 학생이 정해진 기간 내에 이수할 강좌를 신청하는 } \\
\text { 것 }\end{array}$ \\
\hline $\begin{array}{l}\text { 계절 } \\
\text { 학기 }\end{array}$ & $\begin{array}{l}\text { 정규학기 }(1,2 \text { 학기)의 수강 여건을 보완하기 위하여 } \\
\text { 하계 및 동계 방학 중에 실시하는 학기 }\end{array}$ \\
\hline $\begin{array}{l}\text { 성적 } \\
\text { 열람 }\end{array}$ & $\begin{array}{l}\text { 매 학기 기말고사 후 강좌 담당 교수가 부여한 성 } \\
\text { 적을 학생은 전산시스템에서 성적을 열람할 수 있 } \\
\text { 으며 성적에 이의가 있을 때 이의 신청 기간 내에 } \\
\text { 담당교소에게 정정 신청할 수 있음 }\end{array}$ \\
\hline 재이수 & $\begin{array}{l}\text { 이미 취득한 성적이 만족스럽지 못할 경우에는 해 } \\
\text { 당 교과목을 재수강 할 수 있으며 재수강하는 경우 } \\
\text { 이미 취득한 성적은 무효로 함. }\end{array}$ \\
\hline $\begin{array}{l}\text { 학점 } \\
\text { 포기 }\end{array}$ & $\begin{array}{l}\text { 교과목 폐지 등 재수강이 불가능한 교과목의 경우 } \\
\text { 학생의 신청에 의해 이미 취득한 해당교과목의 학 } \\
\text { 점을 } 6 \text { 학점까지 포기할 수 있음. }\end{array}$ \\
\hline $\begin{array}{l}\text { 국내외학 } \\
\text { 점교류 }\end{array}$ & $\begin{array}{l}\text { 대학 간 학술교류협정을 체결한 타 대학과 국외대 } \\
\text { 학에서 학점 이수를 희망하는 학생은 졸업에 필요 } \\
\text { 한 학점의 } 2 \text { 분의 } 1 \text { 범위 내에서 이수 가능 }\end{array}$ \\
\hline $\begin{array}{l}\text { 외부학점 } \\
\text { 인정/자격 }\end{array}$ & $\begin{array}{l}\text { 영어활용능력, 정보활용능력 등의 결과를 학점을 } \\
\text { 인정 }\end{array}$ \\
\hline
\end{tabular}

학사정보는 일반적으로 일반적 분류(학적/수업)와 운영상 분류로 나뉜다. 일반적 분류는 다시 학적과 수업 분야로 나 눌 수 있는데 학적은 휴학, 복학, 전과로 나눌 수 있으며 이 에 필요한 사항으로는 졸업사정, 교직과정이수, 복수전공, 부 전공, 제증명발급등이 있다[5]. 수업은 수강신청, 계절학기, 성적열람, 재이수, 학점포기, 국내외학점교류, 외부학점인정/ 자격증 등의 업무를 필요로 한다[5]. Table 1은 수업과 관련 된 업무를 나타낸다.

대학에서 학생에게 정보를 전달, 공지하는 방법은 크게 공문, 홈페이지, 온/오프라인 통합적 전달방법의 세 분류로 나뉜다[5]. 공문으로 전달하는 방법은 가장 기본적이고 일반 적인 전달 방식으로 학사정보 담당자에 의해 공문이 기안되 고 관리라인의 결재를 얻어 단과대학 행정실로 전달되고 소 속 학과 사무실로 전달된다. 이렇게 공문으로 전달된 학사 정보 내용은 각 학과 게시판에 게시하거나 학과 홈페이지에 내용을 게시하여 최종적으로 학생들이 확인하는 과정을 거
친다. 홈페이지로 전달하는 방식은 학교 홈페이지의 핫뉴스 나 학사공지란 또는 기관 공지란에 학사정보담당자가 게시 한다. 학생들은 게시된 내용을 열람하고 게시판을 통해 문 의와 답변을 확인한다. 현재 대학들에서 일반적으로 사용하 는 방식은 위의 두 가지 방식을 잘 융합한 온/오프라인 통 합적 전달방법이다. 온/오프라인 통합적 전달방법은 공문과 홈페이지를 통한 학사정보가 전달되고 확인될 뿐만 아니라 학생 개인의 성적 또는 이수과목 등 수업관련 기록이나 학 생 개인의 학적 정보에 대하여 개인의 요청에 의해 제 증명 서비스 등의 형태로 전달된다. 이를 그림으로 도식화하면 Fig. 3과 같다.

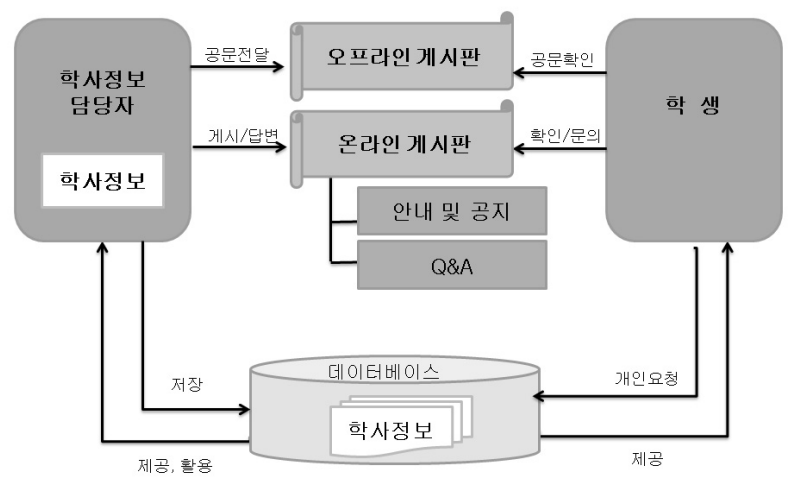

Fig. 3. Integrated transmission method on on-off line

그런데 공문전달에 의한 확인이나 학교홈페이지 공지 확 인의 경우 관심 있는 학생에게만 기회가 주어지고 잠재적으 로 관심을 가질 수 있는 학생에게는 안내의 기회를 놓칠 수 있다는 단점이 있다. 이를 보완하기 위한 것이 메일/SMS 발송 서비스의 활용이다. 메일이나 문자 전송을 할 경우 학 사정보나 일정에 대하여 문자로 확인하고 메일에서 관련 내 용을 접할 기회가 늘어나게 될 것이고 학생 본인의 의지에 의해 기회를 선택할 가능성이 높아진다. 메일이나 SMS서 비스는 Fig. 4와 같은 절차에 따라 운영된다.

학사업무와 관련된 민원은 전화, 사무실 방문 외에도 홈 페이지 $\mathrm{Q} \& \mathrm{~A}$ 를 이용한 민원 등이 있다. 대학의 학과에서 민 원이 처리되는 형태는 Fig. 5와 같다.

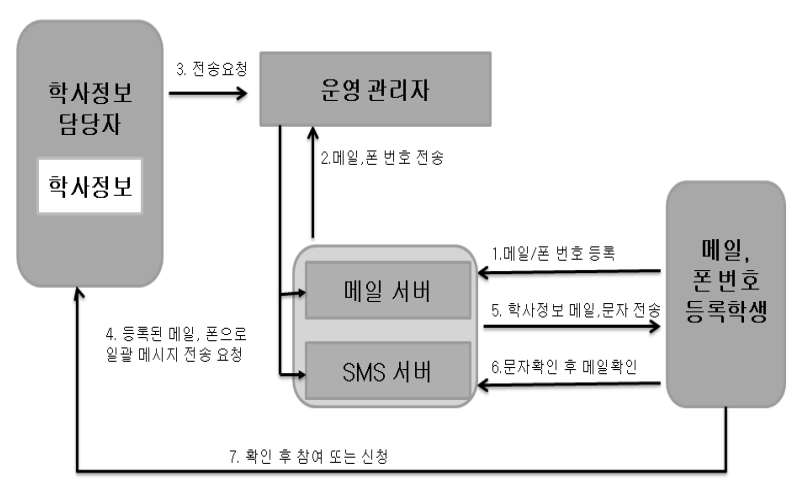

Fig. 4. Transmission procedure of mail and SMS service 


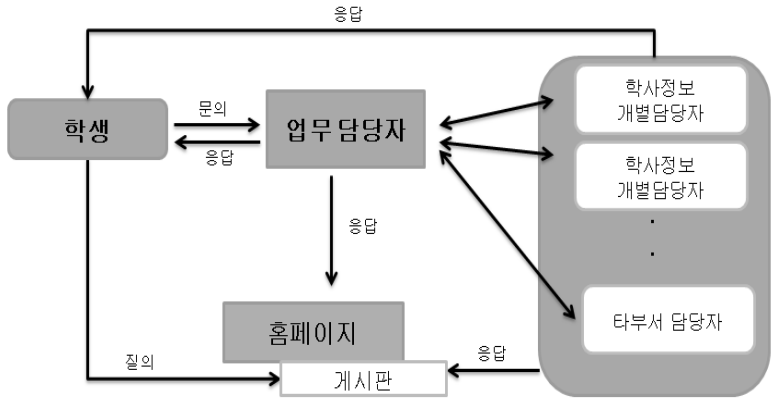

Fig. 5. Procedure of student affairs

학생들의 학사관련 업무처리는 학생에게 학사정보 관련 공지사항을 공지하고 학사일정에 따라 학사관련 신청기간에 관련 사안을 열람, 신청 할 수 있도록 하는 것에서 시작한 다. 학생과 대학과의 연결은 공문전달에 의한 학생의 게시 된 공문확인과 온라인 게시판을 이용한 학사정보의 게시와 확인, 학생의 문의에 대한 답변 등으로 이루어져 있다.

\section{3 기존연구의 문제점 및 해결방안}

기존 대학의 게시판은 오프라인 게시판과 홈페이지를 혼 용하는 것이 대부분이다. 대학에서도 $\mathrm{DID}$ 의 바람이 불고 있 지만 아직은 대학 홍보용 $\mathrm{DID}$ 에 머물러 있는 것이 현실이다.
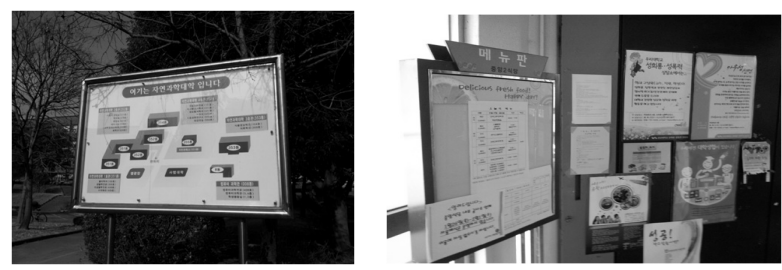

Fig. 6. BBS and advertisement on offline in university

학교 현장에서 활용되는 전자게시판으로 대표적인 것은 고교생을 대상으로 한 대학정보영상게시판인 CompassUni가 있다[11]. CompassUni는 학교 현장에 $\mathrm{DID}$ 를 활용한 대표적 인 사례지만 양방향 맞춤 서비스를 제공하지 못하고 단순히 콘텐츠 재생이라는 초기 DID 활용 수준을 넘지 못하고 있다 는 점에서 개선점이 많다.

고등학교의 경우는 전자게시판이 하나의 자동화 패키지로 운영되는 사례가 일반적인데 대표적인 사례가 전자게시판시 스템이다. 전자게시판시스템은 학교 본관 건물 입구 및 각 교실 복도 시스템을 구축하여 디지털 정보를 제공하는 시스 템으로 용도에 따라 학교 공지 사항 및 규정공지를 위한 $\mathrm{LCD}$ 타입과 터치방식, $\mathrm{RF}$ 카드를 통한 방문자와 학생, 교사에 게 원하는 정보(학교위치, 학교홍보, 교사정보, 학생수업정보 등)를 제공하는 키오스크 타입으로 구분하여 제공한다[12].

이는 고등학교와 같이 작은 단위의 조직에서 체계적으로 운영할 수 있다는 장점이 있다. 그러나 전자게시판시스템은 게시판을 통해 제공할 수 있는 정보가 제한적이고 콘텐츠화 되어 있는 까닭에 게시판을 실시간 양방향 정보 전달의 장

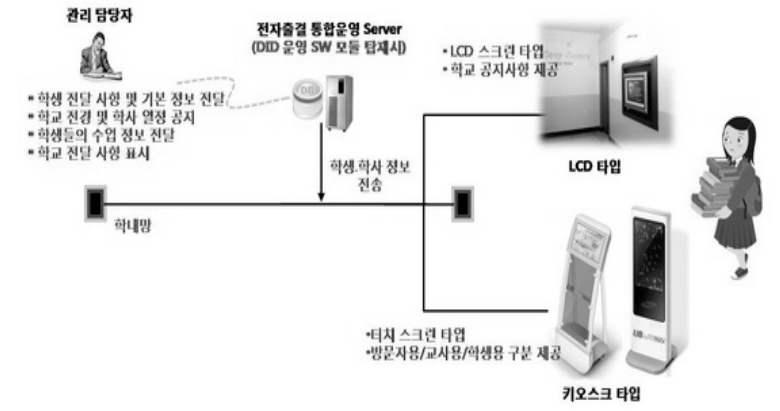

Fig. 7. Electronic BBS

으로 활용하기는 어렵다는 단점이 있다. 대학에서 $\mathrm{DID}$ 는 대 학홍보와 정보제공을 위해 대학본부나 취업부 등에서 많이 활용되고 있는데 대표적인 사례가 충남대학교 게시판이다 [13]. 이는 학과안내와 공지사항, 홍보동영상을 제공하는 유 형으로 여느 게시판과 마찬가지로 이미 만들어진 콘텐츠를 사용자의 선택에 따라 제공하는 홈페이지의 축소판에 지나 지 않는다.

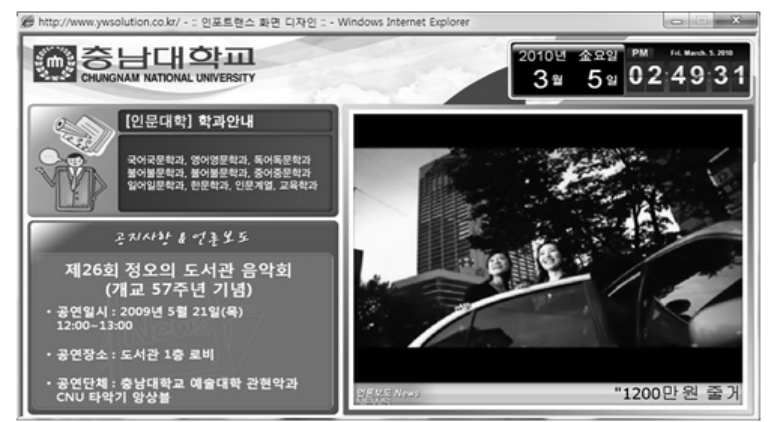

Fig. 8. BBS of Chungnam university

$\mathrm{DID}$ 분야에서는 학교보다 기업, 관공서가 더욱 앞서 가고 있다. 다양한 기관에서 활용하고 있는 대표적인 $\mathrm{DID}$ 소프트웨 어로는 $\mathrm{eLiveAD}$ 가 있다. $\mathrm{eLiveAD}$ 는 콘텐츠 제작용 에디터와 서버 데이터 및 클라이언트 관리용 매니저, 콘텐츠 송출용 플 레이어로 구성되어 있다. eLiveAD는 다양한 소스(Text, Image, Music, Movie, Flash, PPT 등)를 이용한 콘텐츠를 제 작하고 다양한 전송 방식(실시간 전송, 예약 전송, 생방송 등) 으로 전송가능하며 매니저를 통한 플레이어 원격 모니터링으 로 관리 비용을 최소화할 수 있다는 장점이 있다[14].

\section{N-Screen 지원 차세대전자게시판}

대학교 학과 사무실의 게시판을 대체 할 수 있는 차세대 전자 게시판은 관리자가 게시물을 등록하고 학생이 등록된 게시물을 확인할 수 있는 구조로 설계 되었다. 전체 구조는 관리자가 이용하는 서버용과 학생이 내용을 확인할 수 있는 클라이언트용으로 나뉜다. 관리자는 서버에서 게시물을 등 재, 수정, 편집할 수 있으며 관리자가 게시한 게시물은 클라 
Table 2. Affairs of next generation electronic BBS server/client

\begin{tabular}{|c|c|}
\hline \begin{tabular}{c|} 
서버/ \\
클라이언트 \\
\end{tabular} & 역 할 \\
\hline $\begin{array}{l}\text { 클라이언트 } \\
\text { LIVE상태 } \\
\text { (클라이언 } \\
\text { 트 측) }\end{array}$ & $\begin{array}{l}\text {-클라이언트는 일정 시간마다 서버(Activate } \\
\text { Service)로 LIVE 신호를 전송 } \\
\text {-신호 전송 시 서비스로부터 시행 명령이 있는지 } \\
\text { 확인 } \\
\text {-명령이 있다면 호출 결과로 명령을 클라이언트로 } \\
\text { 전송하고 클라이언트는 명령을 실행 }\end{array}$ \\
\hline $\begin{array}{c}\text { 클라이언트 } \\
\mathrm{LIVE} \text { 상태 } \\
\text { (서버 측) }\end{array}$ & $\begin{array}{l}\text {-실버라이트 페이지 로딩 후 Activate Service에 현 } \\
\text { 재 실행중인 클라이언트 목록을 수신 받음 } \\
\text {-클라이언트로 명령 전송 시 클라이언트가 활성 상 } \\
\text { 태가 아니라도 서비스에 명령을 기록함 }\end{array}$ \\
\hline $\begin{array}{l}\text { 서버의 } \\
\text { 게시물 } \\
\text { 등록 }\end{array}$ & $\begin{array}{l}\text {-실버라이트에서 게시물(공지사항, 일정 } \cdots \text { )을 등록 } \\
\text { 시 DB 서비스를 통해 데이터베이스에 기록 } \\
\text {-클라이언트에 실시간으로 수정되어야 하는 정보의 } \\
\text { 경우 각 그룹ID.xml 파일에 수정 시간을 기록 } \\
\text {-그룹ID.xml는 서버를 통해 클라이언트가 http의 } \\
\text { get 형식으로 항상 접근 가능한 위치에 존재함 }\end{array}$ \\
\hline $\begin{array}{l}\text { 게시물 } \\
\text { 실시간수정 } \\
\text { (클라이언 } \\
\text { 트) }\end{array}$ & $\begin{array}{l}\text {-http::/서버주소/Renewal/그룹ID.xml에 접속해 클 } \\
\text { 라이언트 자신이 속한 정보를 읽어옴 } \\
\text {-일정 시간마다 파일을 읽은 후 업 데이트된 카테고 } \\
\text { 리만 읽어 들임. } \\
\text {-수정된 카테고리의 게시물 정보를 } \mathrm{DB} \text { 서비스에 } \\
\text { 접근하여 실제 게시물 정보를 읽어와 화면에 수 } \\
\text { 정시킴 }\end{array}$ \\
\hline
\end{tabular}

이언트에게 일정한 양식에 맞추어 디스플레이 된다. 서버와 클라이언트 구현환경은 Windows 2003 Server, MS SQL Server 2008, Visual Studio, WPF, Silverlight, WCF이며 서버와 클라이언트 측에서 수행하는 작업은 Table 2 와 같다.

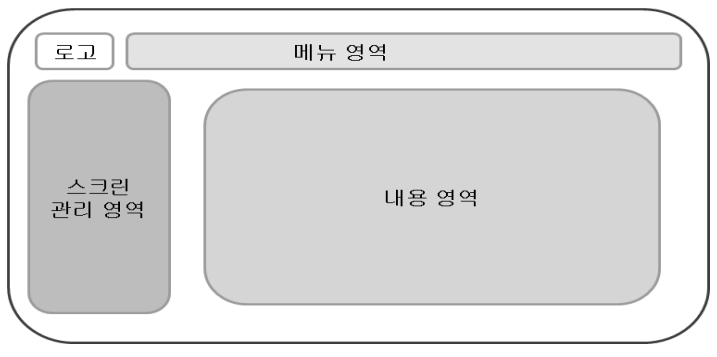

Fig. 10. Components of server

\section{1 서버}

서버는 클라이언트에 출력될 내용을 등록, 수정, 관리하는 영역으로 서버의 메인 화면은 Fig. 10과 같이 구성된다. 서 버는 크게 메뉴영역, 스크린 관리 영역, 내용 영역으로 나뉜 다. 메뉴영역과 스크린 관리 영역 사이에는 로고를 삽입할 수 있게 했다. 여기에는 보통 학과명이 들어간다. 메뉴영역 은 홈, 학과소개, 공지사항, 학사일정, 시간표, 게시물관리, 문자메시지, 정보수정을 기본메뉴로 한다. 대학이나 학과의 특성에 따라서는 메뉴를 더 추가 할 수도 있다. 스크린 관 리 영역은 N-Screen을 위한 기능으로 내용을 표시할 클라 이언트를 조절하도록 한다. 내용 영역은 선택한 메뉴의 내 용이 보이도록 하는 영역으로 기본 값으로 로고등록, 날씨 지역 설정, 즐겨찾기 관리, 뉴스/속보 관리 영역을 제공한다. 날씨와 뉴스/속보는 실시간 정보를 제공한다.

스크린 관리 영역은 시스템의 N-Screen을 조절하도록 구 현된 영역으로 클라이언트를 등록하고 정보를 해당 클라이

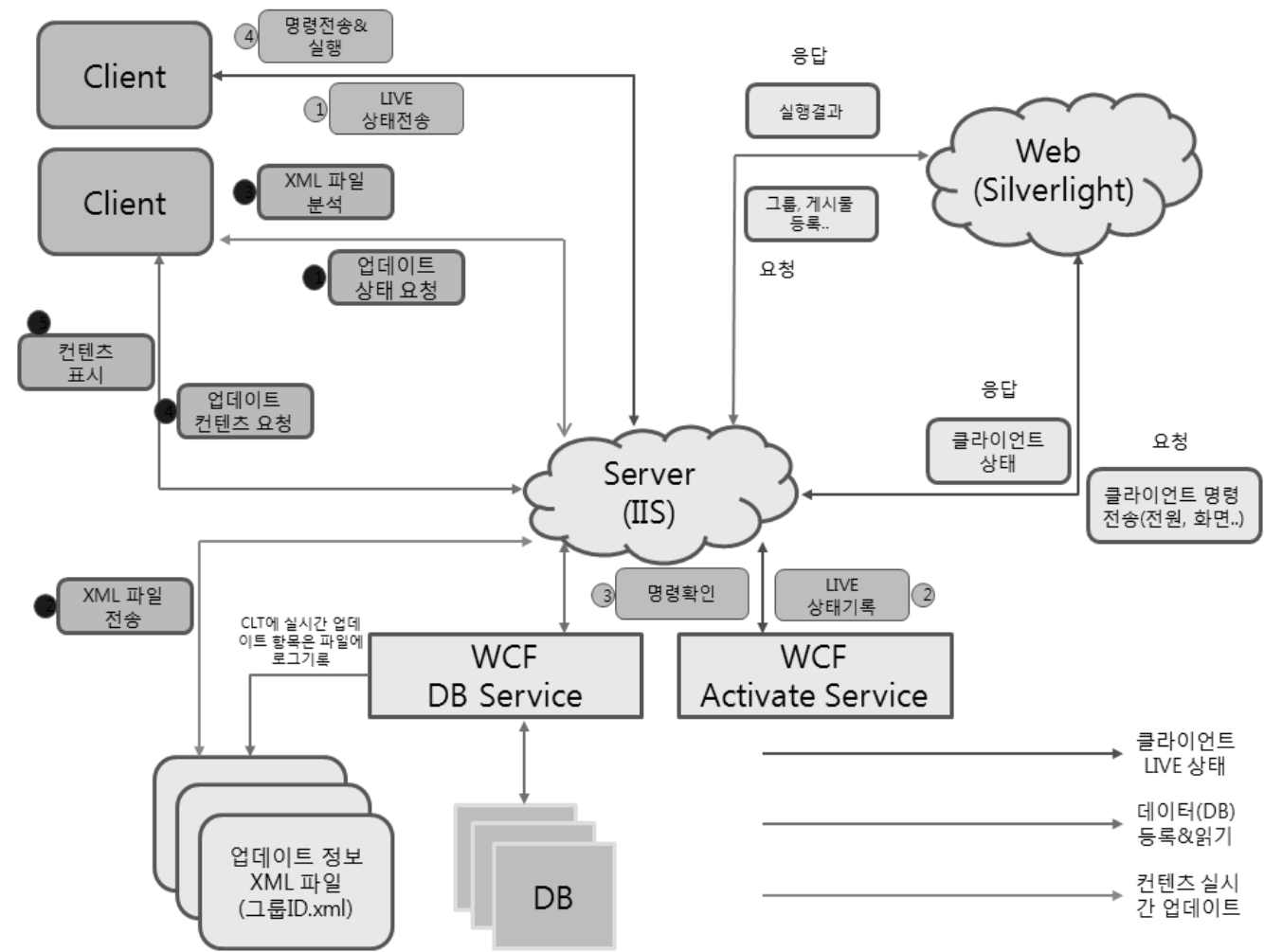

Fig. 9. Overall flow of next generation electronic BBS 
언트에 표시할지 여부를 조절할 수 있는 영역이다. 메뉴에 서는 클라이언트를 실행시키면 기본 값으로 보이는 내용을 설정하는 곳이다.

\section{2 클라이언트}

클라이언트는 서버에서 등록, 설정한 내용에 따라 화면이 출력되는 부분으로 Fig. 11은 클라이언트의 구성도를 나타 낸다.

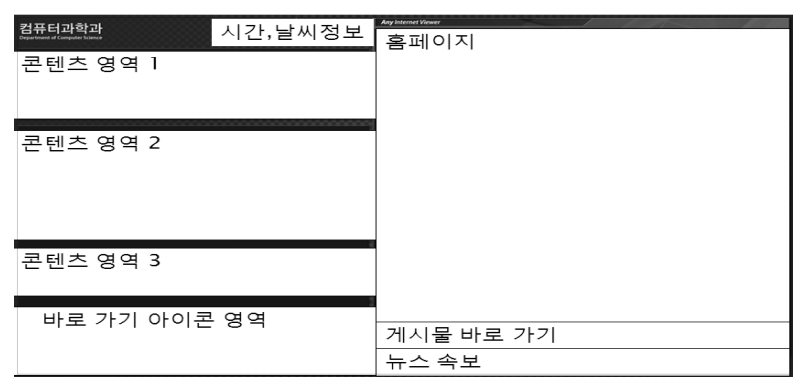

Fig. 11. Components of client

클라이언트는 서버에서 설정한 시간, 날씨정보를 출력하 는 영역, 콘텐츠를 표시하는 영역, 홈페이지를 표시하는 영 역, 뉴스정보를 제공하는 영역이 있다. 그 외에도 클라이언 트의 사용 편의성을 제공하기 위해 바로가기 아이콘 영역과 게시물 바로가기 영역을 설계 및 구현하였다. 홈페이지를 표시하는 영역은 즐겨찾기에 등록한 바로가기 아이콘을 통 해서 제공된다. 즐겨찾기의 바로가기 아이콘은 서버의 홈 메뉴에서 이미 설정해 놓은 값이다. 클라이언트의 초기 실 행 모습은 Fig. 12 와 같다.

\section{4. 실험 및 평가}

\section{1 실행 결과}

차세대 전자게시판 서버 프로그램은 초보자들도 쉽게 사 용할 수 있도록 구성되어 있다. 차세대 전자게시판의 초기

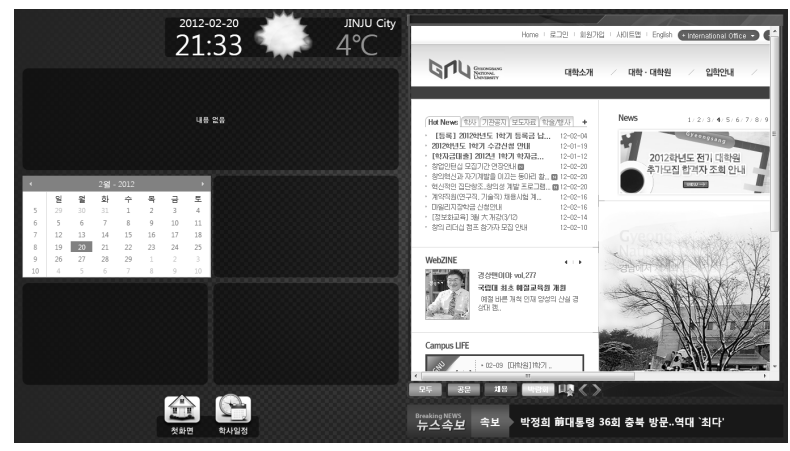

Fig. 12. First screen of client

화면은 Fig. 13 과 같다. 3 장에서 언급한 것과 같이 홈, 학과 소개, 공지사항, 학사일정, 시간표, 게시물관리, 이메일, 정보 수정을 메뉴를 가진다. 본 절에서는 서버의 설정을 통해 클 라이언트가 어떻게 보이는 지를 실행 예를 통해 보인다. 초 기 상태에서 서버의 홈메뉴의 로고이미지, 날씨지역, 즐겨찾 기관리, 뉴스/속보 내용을 Fig. 14와 같이 수정하면 클라이 언트에 반영된다.

서버의 게시물 관리 메뉴에서 Fig. 15 와 같이 게시물을 등록, 삭제 할 수 있고, 게시물을 등록 할 때는 공문, 채용, 박람회 세 영역으로 분류한다.

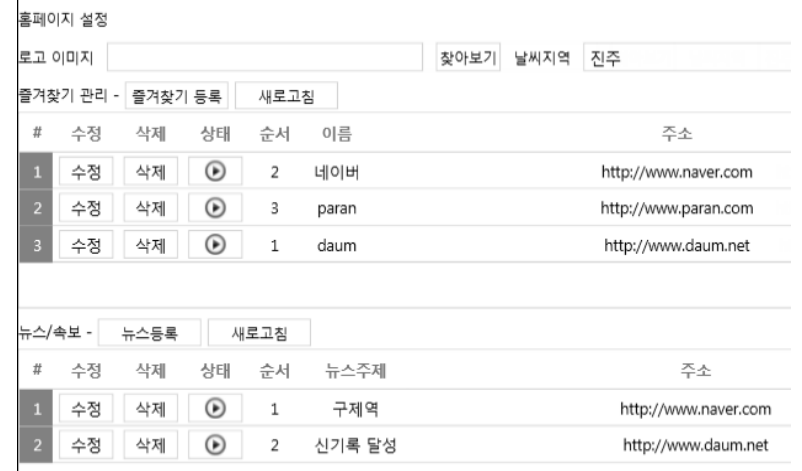

Fig. 14. Home menu update of server

\begin{tabular}{|c|c|c|c|c|c|c|c|c|c|c|c|c|c|c|c|}
\hline \multirow{2}{*}{\multicolumn{2}{|c|}{$\begin{array}{l}\text { 로고 틀어갈 자리 } \\
\text { com1 }\end{array}$}} & & & 홀 & 학과소개 & 공학 & 인증 & 서울어코드 & 공지사항 & 학사일정 & 시간표 & 거시술관리 & 문자메 & & 이어일 \\
\hline & & & & \multicolumn{12}{|l|}{ 홀페이지 설정 } \\
\hline \# & 클라이언트 & 상태 & 수정 & 로고 이미지 & & & & & 찾아보기 & \multirow[t]{2}{*}{ 날씨지역 } & \multicolumn{2}{|c|}{ 지역을 선택하세요. 현재 : } & \multirow[t]{2}{*}{ 미지정 } & \multirow[t]{2}{*}{$\bullet$} & \multirow[t]{2}{*}{ 저장 - } \\
\hline & & & & \multicolumn{3}{|c|}{ 쫄겨잦기 관리 - 쯜겨잦기 등록 } & 새로고 & & & & & & & & \\
\hline & & & & \# 수정 & 삭제 & 상태 & 순서 & 이름 & & & & & \multicolumn{2}{|c|}{ 주소 } & \\
\hline & \multicolumn{3}{|c|}{ 글라이언트가 존재하지 않슴니다! } & 뉴스/속보 - & 뉴스등록 & \multicolumn{2}{|c|}{ 새로고침 } & & & & & & & & \\
\hline & & & & \# 수정 & 삭제 & 상태 & 순서 & 뉴스주제 & & & & & \multicolumn{2}{|c|}{ 주소 } & \\
\hline
\end{tabular}

Fig. 13. First screen of server 


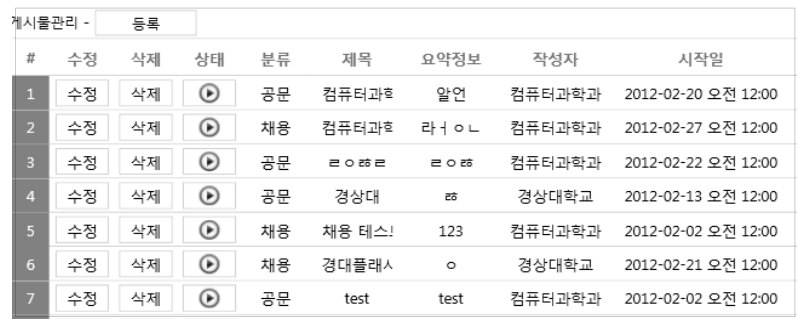

Fig. 15. Enrollment of posts

클라이언트에서는 등록된 게시물을 선택적으로 확인할 수 있다. Fig. 16은 등록된 게시물중 분류가 '채용'인 것만을 추 출한 예이다.

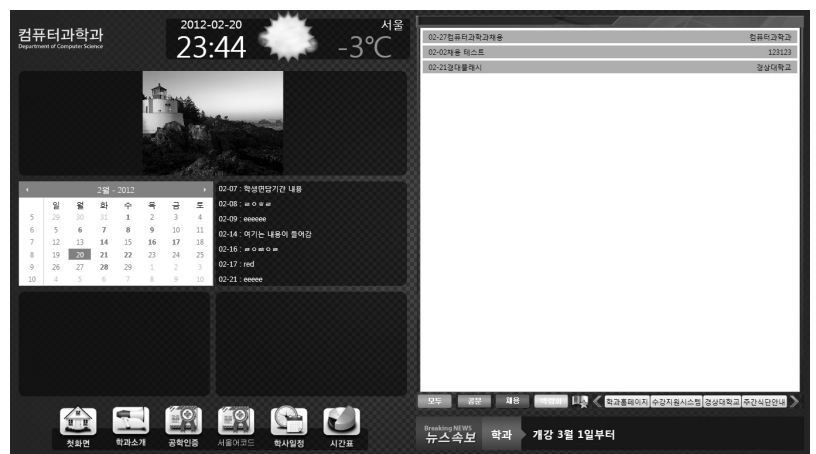

Fig. 16. View result of posts concerned on recruit

\section{2 평가 결과}

본 연구는 대학 학과용 전자게시판을 $\mathrm{N}-\mathrm{Screen}$ 을 지원하 는 양방향 온라인 시스템을 옮긴 것으로 대학의 DID 활용 의 또 다른 사례를 제공한다. 차세대 전자게시판은 오프라 인 게시판이 안고 있는 우선순위 선택에 따른 시간과 노력 의 소모, 게시판 인테리어의 취약, 관리 효율성 저하, 표출 정보 제한성에 따른 정보효과 미흡, 정보 전달의 시공간적 제약점이라는 문제점을 해결한다. Table 3은 2012년 4월 모 대학 평균학과별 게시물 사용현황을 조사한 결과이다.

Table 3. Current states using posts by department of university

\begin{tabular}{|c|c|c|c|c|c|c|}
\hline 학과 & $\begin{array}{l}\text { 총게시 } \\
\text { 물수 }\end{array}$ & $\begin{array}{l}\text { 게시물 } \\
\text { 사용률 }\end{array}$ & $\begin{array}{c}\text { 홈페이지 } \\
\text { 연동수 }\end{array}$ & $\begin{array}{l}\text { 홈페이지 } \\
\text { 연동률 }\end{array}$ & 만료 & 파일 형식 \\
\hline $\begin{array}{l}\text { 컴퓨터 } \\
\text { 과학과 }\end{array}$ & 11 & $73 \%$ & 3 & $27 \%$ & 1 & $\begin{array}{l}\text { hwp,jpeg, } \\
\text { 포스터,pdf }\end{array}$ \\
\hline $\begin{array}{l}\text { 컴퓨터 } \\
\text { 교육과 }\end{array}$ & 18 & $90 \%$ & 1 & $11 \%$ & 0 & $\begin{array}{l}\text { hwp,jpeg, } \\
\text { 포스터,doc }\end{array}$ \\
\hline 화학과 & 7 & $35 \%$ & 1 & $14 \%$ & 0 & $\begin{array}{c}\text { hwp,jpeg, } \\
\text { 포스터 }\end{array}$ \\
\hline 물리교육과 & 17 & $85 \%$ & 3 & $18 \%$ & 1 & $\begin{array}{c}\text { hwp,jpeg, } \\
\text { 포스터 }\end{array}$ \\
\hline 생물교육과 & 6 & $30 \%$ & 1 & $17 \%$ & 0 & $\begin{array}{c}\text { hwp,jpeg, } \\
\text { 포스터 }\end{array}$ \\
\hline 생물학과 & 19 & $95 \%$ & 2 & $11 \%$ & 3 & $\begin{array}{c}\text { hwp,jpeg, } \\
\text { 포스터 }\end{array}$ \\
\hline 미생물학과 & 6 & $30 \%$ & 0 & $0 \%$ & 2 & $\begin{array}{c}\text { hwp,jpeg, } \\
\text { 포스터 }\end{array}$ \\
\hline
\end{tabular}

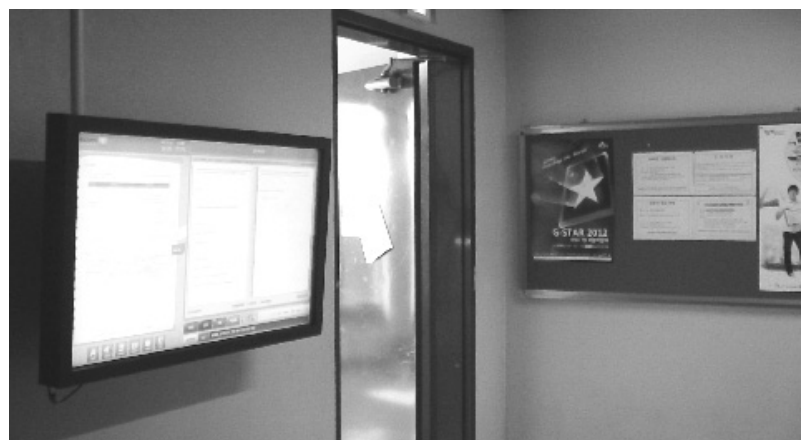

Fig. 17. Screen on installing and operating at real

게시물의 사용률을 보면 $50 \%$ 미만인 게시물들이 많이 있 는 것을 볼 수 있으며, 이것은 한 달 동안 한 번도 아무도 접근하지 않은 것을 의미한다.

Fig. 17은 모 대학 컴퓨터과학과에 학생들이 가장 많이 다니는 곳에 설치하여 실제 운용 중에 있는 것을 보이고 있 다. 2012년 9월 중에 설치하여 1달 동안 운영해 본 결과, 학 생들의 많은 관심을 이끌어 낼 수 있었고, 학과에 다양하게 일어나는 일들을 학생들이 참여할 수 있었음을 볼 수 있었 다. Table 4 는 기존의 홈페이지 방식과 오프라인 게시판을 함께 운용한 결과와 제안 시스템을 설치 후의 결과를 보이 고 있다. 설치 후 학생들의 게시판 접속빈도와 학과 일의 참여도가 증가한 것을 볼 수 있으며, 개인별 게시판 접속 비율은 한 학생이 하나의 게시물에 접속하는 비율을 나타낸 다. 기존 시스템에서는 학과 학생의 $51 \%$ 만이 게시판에 접속 했으며, 제안 시스템을 설치 후에는 $88 \%$ 의 학생들이 게시판 에 접속을 하였다. 비록 한 달 동안 수렴된 결과이긴 하지 만 제안 시스템이 충분히 효과적인 게시판임을 인정하기에 는 충분하다.

Table 4. Before-after comparisons of the proposed BBS

\begin{tabular}{c|c|c|c}
\hline 시스템 명 & $\begin{array}{c}\text { 게시물 } \\
\text { 접속빈도 } \\
\text { (월 평균) }\end{array}$ & $\begin{array}{c}\text { 학과일 } \\
\text { 참여도 }\end{array}$ & $\begin{array}{c}\text { 개인별 게시판 } \\
\text { 접속 비율 } \\
\text { (중복 제외) }\end{array}$ \\
\hline $\begin{array}{c}\text { 기존 시스템 } \\
\text { (2012년 3-6월) }\end{array}$ & 156 & (12회) $39 \%$ & $\begin{array}{c}51 \% \\
\text { (중복 제외) }\end{array}$ \\
$\begin{array}{c}\text { 제안 시스템 } \\
\text { (2012년 10월) }\end{array}$ & 562 & (4회) $58 \%$ & $\begin{array}{c}88 \% \\
\text { (설문 조사 결과) }\end{array}$ \\
\hline
\end{tabular}

Table 5는 타 시스템과의 비교로 차세대 전자게시판은 $\mathrm{N}-\mathrm{Screen}$ 을 지원하고 게시물을 실시간으로 삽입, 삭제하여 오프라인 게시판과 홈페이지를 대체 할 수 있다는 점에서 타 시스템에 비해 성능이 우수하다는 것을 보이고 있다.

\section{5. 결 론}

본 연구는 대학의 오프라인 게시판을 온라인 게시판으로 옮긴 차세대 전자게시판 시스템에 관한 것이다. 차세대 전 
Table 5. Comparisons between the proposed system and the other system

\begin{tabular}{c|c|c|c|c|c|c}
\hline 시스템명 & $\begin{array}{c}\text { 게시물 } \\
\text { 등록 }\end{array}$ & $\begin{array}{c}\text { 동영상 } \\
\text { 재생 }\end{array}$ & $\begin{array}{c}\text { N-Screen } \\
\text { 지원 }\end{array}$ & $\begin{array}{c}\text { 콘텐츠 } \\
\text { 열람 }\end{array}$ & $\begin{array}{c}\text { 콘텐츠 } \\
\text { 등록 }\end{array}$ & $\begin{array}{c}\text { 양방향 } \\
\text { 커뮤니케이션 }\end{array}$ \\
\hline 차세대전자게시판 & 가능 & 가능 & $\mathrm{O}$ & $\mathrm{O}$ & $\mathrm{O}$ & $\mathrm{O}$ \\
충남대학교게시판 & 불가능 & 가능 & $\mathrm{X}$ & $\mathrm{O}$ & $\mathrm{X}$ & $\mathrm{X}$ \\
CompassUni & 불가능 & 가능 & $\mathrm{X}$ & $\mathrm{O}$ & $\mathrm{X}$ & $\mathrm{X}$ \\
\hline
\end{tabular}

자게시판은 기존의 오프라인 게시판이 갖고 있는 단점을 해 결한 것으로 대학 학과의 관리자가 원하는 정보를 게시하고 학생은 $\mathrm{LCD}$ 스크린, 모바일 등을 이용하여 원하는 장소에서 정보를 확인 할 수 있다. 지원 기능은 콘텐츠 전파, $\mathrm{N}-\mathrm{Screen}$ 지원, 관리자 이메일 전송, 클라이언트 원격 관리 를 지원하며 기존 대학정보 시스템과도 연동이 가능하다. 본 연구는 기존의 유사한 시스템에 비해 월등히 우수하다는 것을 실험으로 보였으며, 앞으로 해결해야 할 과제로는 학 과의 개념에서 좀 더 확대하여 대학-학부-학과로 이어지는 큰 시스템에서의 정보 전달 체계를 연구하여야 한다. 또한 $\mathrm{SMS}$ 알림 서비스를 구현을 통해 게시물이 등록되면 자동으 로 메시지가 전달되도록 하여 사용자의 정보 접근성을 높일 수 있도록 해야 한다.

\section{참 고 문 헌}

[1] ITWORLD(http://www.itworld.co.kr/news/52953), "DIS market scale, growing $10 \%$ every year".

[2] Ralto Inc., (http://www.lalto.co.kr/v2/product200810.html), "Any Time! Any Where".

[3] J. H. Choi, "Examples constructing the content service of N-Screen”, KIISE Magazine, Vol.29, No.7, pp.55-60, 2011.

[4] S. W. Kim,, "Building a sustainable UX ecosystem under $\mathrm{N}-$ Screen and cloud computing paradigm", Korea human engineering society transactions, Vol.29, No.4, pp.553-561, 2012.

[5] GNU Information Market (http://service.gnu.ac.kr/sub /03_01.jsp).

[6] H. S. Kim, H. J. Lee, and G. S. Cho, "Overview of status and R\&D issues on N-Screen service”, KIISE Magazine, Vol.29, No.7, pp.9-15, 2011.

[7] S. H. Lee, "Realtime digital information display system based on web server", KSCI Transcations, Vol.14, No.1, pp.153-161, 2009.

[8] BBMC Inc., (http://www.signcast.co.kr).
[9] Y. I. Yoon, and S. Kim, "The consideration of standard and the strategy emergence for N-Screen", KIISE Transactions, Vol.29, No.7, pp.16-22, 2011.

[10] Y. I. Yoon, S. Kim, M. G. In, G. C. Lee, and S. Y. Lee, “A service strategy of N-Screen base on mobile cloud”, KICS Magazine, Vol.28, No.10, pp.38-43, 2011.

[11] Daco industry laboratory, "Development trend of the industry related on smart TV opening N-Screen generation", Market snalysis, Daco, pp.8-30, 2011.

[12] UB infotec Inc., (http://www.ubinfotech.com).

[13] Yonwoo solution Inc., (http://ywsolution.co.kr).

[14] Pid Korea Inc., (http://pidkorea.com/index.php).

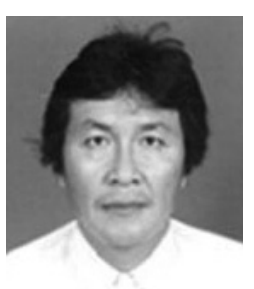

박 재 흥

e-mail : pjh@gnu.ac.kr

1978년 충북대학교 수학교육과

1989년 중앙대학교 전산과(박사)

1983년 현 재 경상대 컴퓨터과학과 교수 관심분야: 소프트웨어 공학, 테스팅, 소프트 웨어 신뢰성, Medical Imaging

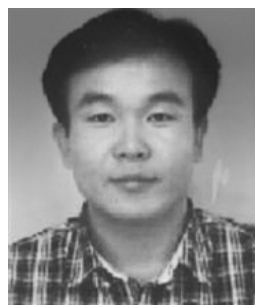

서 영 건

e-mail : young@gnu.ac.kr 1987년 경상대학교 전산과(학사) 1997년 숭실대학교 전산과(박사) 1989년 1992년 삼보컴퓨터 1997년 2011년 경상대학교 컴퓨터교육과 교수

2011년 현 재 경상대학교 컴퓨터과학과 교수 2001년 현 재 경상대학교 컴정통신연구소원 2011년 2012년 UNC at Chapel Hill, Visiting Scholar 관심분야: Medical Imaging, Image Segmentation, Computer Network 